\title{
NEW MULTIPLICATIVE HIGHER ORDER DYNAMIC INEQUALITIES OF OPIAL TYPE
}

\author{
Safi S. Rabie, S. H. Saker, D. O'Regan and R. P. Agarwal
}

Abstract. In this paper, we prove some new multiplicative dynamic inequalities of Opial type on a time scale $\mathbb{T}$. The main results will be proved by using Hölder's inequality, the chain rule and some basic dynamic inequalities designed and proved for this purpose. As special cases, we will derive some continuous and discrete inequalities from the main results.

Mathematics subject classification (2010): 26A15, 26D10, 26D15, 39A13, 34A40.

Keywords and phrases: Opial's inequality, partial derivatives, Shum's inequalities, time scales.

\section{REFERENCES}

[1] R. P. Agarwal And M. Bohner, Basic Calculus on Time Scales and Some of its Applications, Results Math. 35 (1999), 3-22.

[2] R. P. Agarwal, D. O’Regan, And S. SAKer, Dynamic Inequalities on Time Scales, Springer, Cham, 2014.

[3] G. Anastassiou, Time scales inequalities, Int. J. Difference Eqns. 5 (2010), 1-23.

[4] M. Bohner And A. Peterson, Dynamic Equations on Time Scales: An Introduction with Applications, Birkhäuser, Boston, 2001.

[5] M. Bohner And A. Peterson, Advances in Dynamic Equations on Time Scales, Birkhäuser, Boston, 2003.

[6] M. Bohner And B. KAYMAKÇAlan, Opial Inequalities on Time Scales, Annal. Polon. Math. 77 (2001), 11-20.

[7] M. Bohner, R. R. Mahmoud, And S. H. SAKer, Discrete, continuous, delta, nabla, and diamondalpha Opial inequalities, Math. Inequal. Appl. 18 (2015), 923-940.

[8] M. Bohner, R. R. Mahmoud, And S. H. SAKer, Improvements of dynamic Opial-type inequalities and applications, Dynam. Systems Appl. 24 (2015), 229-242.

[9] W. S. Cheung, Some New Opial-Type Inequalities, Mathematika 37 (1990), 136-142.

[10] R. J. Higgins And A. Peterson, Cauchy functions and Taylor's formula for Time Scales $\mathbb{T}$, in Proceedings of the 6th International Conference on Difference Equations, pp. 299-308, CRC, Boca Raton, Fla, USA, 2004.

[11] B. KARPUZ AND U. M. ÖCLAn, Some Generalizations for Opial's Inequality Involving Several Functions and Their Derivatives of Arbitrary Order on Arbitrary Time Scales, Math. Ineq. App. 14 (2011), 79-92.

[12] W. G. Kelley And A. C. Peterson, Difference Equations; An Introduction with Applications, Academic Press, New York 1991.

[13] S. H. S AKeR, Opial's Type Inequalities on Time Scales and Some Applications, Annales. Polon. Math. 104 (2012), 243-260.

[14] S. H. SAKer, New Inequalities of Opial's Type on Time Scales and Some of Their Applications, Discrete Dynamics in Nature and Society, vol. 2012, Article ID362526, 23 pages, 2012.

[15] H. M. Srivastava, Kuei-Lin Tseng, Shio-Jenn Tseng, Jen-Chieh Lo, Some Generalizations of Maroni's Inequality on Time Scales, Math. Ineq. Appl. 14 (2011), 469-480.

[16] H. M. Srivastava, Kuei-Lin Tseng, Shio-Jenn Tseng, Jen-Chieh Lo, Some Weighted Opial type Inequalities on Time Scales, Taiwanese J. of Math. 14 (2010), 107-122. 
[17] F. H. Wong, W. C. Lin, S. L. Yu And C. C. YeH, Some Generalization of Opial's Inequalities on Time Scales, Taiwanese J. of Math 12 (2008), 463-471. 